\title{
Pencegahan PenodaAn Agama PERSPEKTIF FIQH JINÂYAH
}

\author{
Ahmad Habibullah SMP Kedung Megarih Kembang Bahu \\ habibieahmad12@yahoo.com Lamongan
}

\begin{abstract}
This article discusses the Islamic criminal Law (fiqh jinâyah) analysis on prevention of blasphemy in Indonesia. Law No. 1 Year 1965 concerning with prevention of religion abuse and/or blasphemy and Criminal Code which see criteria regarding the banned or misguided sects or organizations that are also stipulated in the provisions of MUI (Indonesian Ulama Council) in 2007. The laws state that the legal sanction against the perpetrators of the desecration of religion is imprisoned for ever five years. In Islamic criminal Law, the detailed criteria of blasphemy can only slightly be met due to the absence of the text of either al-Qur'an or al-Hadith that explain in detail about the legal sanction of blasphemy. Application of the legal punishment which based on the wisdom of judge can be used against blasphemy. Such a legal punishment is in line with the existing legal sanction in UUPNPS. This is when the offense of blasphemy committed is rated light. On the other hand, if the offense of blasphemy is considered very heavy and has a very great effect, it can be the opposite.

Keywords: Blasphemy, legal sanction, Islamic criminal law.
\end{abstract}

Abstrak: Artikel ini membahas tentang analisis fikih jinâyah tehadap pencegahan penodaan agama di Indonesia. Undang-Undang Nomor 1 Tahun 1965 Tentang Pencegahan Penyalahgunaan dan atau Penodaan Agama maupun KUHP, melihat kriteria mengenai aliran/organisasi yang terlarang atau sesat yang tertuang dalam ketentuan hukum tersebut yang dikuatkan pula oleh fatwa MUI pada tahun 2007, dinyatakan bahwa sanksi hukum terhadap pelaku penodaan agama adalah dengan pidana penjara selama-lamanya lima tahun. Dalam Figh Jinâyah, kriteria penodaan agama secara terperinci dapat ditemui meskipun hanya sedikit, dikarenakan tidak adanya nash al-Qur'an maupun Hadis yang menjelaskan secara detail mengenai penodaan agama beserta sanksi hukumnya. Penerapan hukuman ta'zir yang berdasarkan kearifan hakim, digunakan untuk menjerat pelaku penodaan agama. Hukuman ta'zîr ini sejalan dengan sanksi hukum yang ada dalam UUPNPS, hal ini bila delik penodaan agama yang dilakukan dinilai ringan. Tetapi di sisi lain akan sangat bertolak belakang, apabila delik penodaan agama dinilai sangat berat dan besar pengaruh yang ditimbulkan.

Kata Kunci: Penodaan agama, sanksi, fiqh jinâyah. 


\section{Pendahuluan}

Masyarakat Indonesia merupakan masyarakat yang majemuk, khususnya bisa dilihat dari segi kebudayaan, etnis, ras, suku bangsa, dan agama. Konsekuensinya dalam menjalani kehidupan, masyarakat Indonesia dihadapkan pada perbedaan dalam berbagai hal, mulai dari kebudayaan, cara pandang hidup, dan interaksi antara individu satu dengan individu yang lain, serta dalam keyakinan untuk mempercayai suatu agama yang dianggapnya benar.

Beragamnya ketentuan agama dalam hukum Indonesia, menunjukkan bahwa agama adalah unsur penting yang menjiwai kehidupan berbangsa, bernegara dan bermasyarakat di Indonesia. Ketentuan pembukaan UUD 1945 paragraf satu secara tegas menjelaskan bahwa kemerdekaan bangsa bukan hanya akibat dari perjuangan materiil semata, melainkan juga akibat dari "berkat Rahmat Tuhan yang Maha Esa”.

Pencantuman sila pertama "Ketuhanan Yang Maha Esa" dalam Dasar Negara Pancasila dan penegasan konstitusional dalam Pasal 29 ayat (1) UUD 1945 bahwa "Negara berdasarkan atas Ketuhanan Yang Maha Esa", dengan jelas membuktikan pengakuan negara bahwa Tuhan Yang Maha Esa adalah "causa prima" dalam kehidupan berbangsa, bernegara, dan bermasyarakat. ${ }^{1}$ Penegasan tersebut pada suatu pihak membuktikan bahwa Indonesia bukan negara yang netral agama, tetapi pada pihak lain bertitik tolak dari kebhinnekaan masyarakat Indonesia, khususnya kemajemukan dalam agama dan kepercayaan, maka negara Indonesia juga tidak didirikan di atas dasar salah satu agama. Oleh sebab itu seluruh hukum yang dibuat oleh negara atau pemerintah dalam arti yang seluas-luasnya, tidak boleh bertentangan dengan hukum Tuhan, bahkan lebih dari itu, setiap tertib hukum yang dibuat, haruslah didasarkan atas dan ditujukan untuk merealisir hukum Tuhan. ${ }^{2}$

Selain ketentuan dalam UUD, ketentuan hukum tentang agama juga dapat ditemukan dalam Penetepan Presiden Nomor 1 Tahun 1965 tentang Pencegahan Penyalahgunaan dan/atau Penodaan Agama, yang berdasarkan Undang-undang Nomor 5 Tahun 1969 tentang Pernyataan Berbagai Penetapan Presiden dan Peraturan Presiden Sebagai Undang-

\footnotetext{
${ }^{1}$ As'ad Said Ali, Negara Pancasila Jalan Kemaslahatan Berbangsa (Jakarta: LP3ES, 2009), 157-159.

2 Juhaya S. Praja dan Ahmad Syihabuddin, Delik Agama dalam Hukum Pidana Di Indonesia (Bandung: Penerbit Angkasa, 1982), 1.
} 
undang. Penetapan presiden tersebut ditingkatkan menjadi Undangundang Nomor 1/PNPS/1965 (selanjutnya disebut UUPNPS) ${ }^{3}$. Dalam UUPNPS menyebutkan, bahwa:

Setiap orang dilarang dengan sengaja di muka umum menceritakan, menganjurkan atau mengusahakan dukungan umum, untuk melakukan penafsiran tentang sesuatu agama yang dianut di Indonesia atau melakukan kegiatan-kegiatan keagamaan yang menyerupai kegiatan-kegiatan keagamaan dari agama itu, penafsiran dan kegiatan mana menyimpang dari pokok-pokok ajaran agama itu. ${ }^{4}$

Ketidakjelasan rumusan delik terhadap agama yang ada dalam setiap peraturan di Indonesia, berimbas tidak seimbangnya hukuman terhadap pelaku pelanggaran delik agama. Hukuman yang sepantasnya dijatuhkan harusnya bertujuan agar tidak adanya balasan dari apa yang telah dilakukan, menjadikan hukuman sebagai bahan perbaikan dan pengajaran, serta bertujuan agar pelaku tidak mengulangi perbuataan pidananya untuk kedua kalinya. Di samping itu juga merupakan tindakan preventif bagi orang lain untuk tidak melakukan tindakan yang sama. ${ }^{5}$ Dalam UUPNPS orang, penganut, anggota dan/atau anggota pengurus organisasi yang bersangkutan dari suatu aliran yang menyimpang dari ajaran pokok-pokok agama/aliran sesat dipidana dengan pidana penjara selama-lamanya lima tahun. Hal ini sama dengan ketentuan yang ada dalam KUHP pasal 156a.

Melihat ketentuan di atas, sanksi hukuman terhadap pelaku aliran sesat ini dirasa tidak pantas. Hal ini semakin menunjukan ketidak tegasan UUPNPS dalam menjerat pelaku pidana, karena banyaknya delik agama yang belum diatur serta aturan hukuman pidana yang berkesan ringan. Padahal ancaman pelecehan agama tidak saja sebatas permasalahan individu maupu kelompok agama, melainkan juga mengancam ketentraman serta persatuan kehidupan bernegara. Selain itu, juga bertentangan dari penjelasan umum UUPNPS yang dimaksudkan untuk melindungi ketentraman orang beragama terhadap penodaan/penghinaan agama dan ajaran-ajaran tidak memeluk agama. ${ }^{6}$

\footnotetext{
${ }^{3}$ Istilah penyebutan Undang-undang No. 1 Tahun 1965 tentang Pencegahan Penyalahgunaan dan atau Penodaan Agama. Selanjutnya akan di sebut UUPNPS.

${ }^{4}$ Pasal 1 UUPNPS Tahun 1965

${ }^{5}$ Rahmat Hakim, Hukum Pidana Islam (Fiqh Jinayah)(Bandung: Pustaka Setia, 2000), 63.

${ }^{6}$ Wirjono Prodjodikoro, Tindak-Tindak Pidana Tertentu di Indonesia (Bandung: Refika Aditama, 2008), 151.
} 
Dalam Islam mengatur hubungan timbal balik antara Sang Pencipta dengan makhluk ciptaanya/individu (habl min Allâh), serta hubungan antara individu satu dengan individu yang lainnya (habl min al-nâs). Agama Islam juga melarang perbuatan menjelekkan suatu agama atau kepercayaan lain, hal ini diupayakan untuk mengurangi gesekangesekan antar individu karena perbedaan pemahaman serta keyakinan yang berujung pada penghinaan, penghujatan, penodaan, atau pelecehan. Seperti yang tertuang dalam al-Qur'an Surat al-Maidah ayat 57 yang berbunyi:

"Hai orang-orang yang beriman, janganlah kamu mengambil sebagai pemimpinmu, orang-orang yang membuat agamamu jadi buah ejekan dan permainan, (yaitu) di antara orang-orang yang telah diberi kitab sebelummu, dan orang-orang yang kafir (orangorang musyrik). Dan bertakwalah kepada Allah jika kamu betulbetul orang-orang yang beriman". (QS Al-Maidah: 57).?

Larangan melecehkan/menghina dalam agama Islam dapat dilihat dalam al-Qur'an surat al-An'am ayat 108, yang berbunyi:

"Dan janganlah kamu memaki sembahan-sembahan yang mereka sembah selain Allah, karena mereka nanti akan memaki Allah dengan melampaui batas tanpa pengetahuan. Demikianlah Kami jadikan setiap umat menganggap baik pekerjaan mereka. Kemudian kepada Tuhanlah mereka kembali, lalu Dia memberitakan kepada mereka apa yang dahulu mereka kerjakan". (QS Al-An'am: 108). ${ }^{8}$

Islam belum mengatur sepenuhnya mengenai hukuman terhadap pelaku aliran sesat maupun pelecehan/penodaan agama. Hanya saja larangan-larangan untuk melecehkan agama sudah jelas terdapat di alQur'an. Atas hukuman-hukuman atau jarîmah-jarîmah (tindak pidana) yang tidak terdapat maupun tidak ada ketetapannya dalam shara', alQur'an maupun hadis dapat dikenakan dengan jarîmah ta'zîr. Hukuman ta'zîr dapat dijatuhkan apabila hal itu dikehendaki oleh kemaslahatan umum, meskipun perbuatannya bukan maksiat. Perbuatan-perbuatan yang termasuk kelompok ini mengandung unsur

\footnotetext{
${ }^{7}$ Departemen Agama Rl, Al-Qur'an dan Terjemahan dengan Transliterasi (Semarang: Asy-Syifa', 2000), 246.

8 Ibid., 296.

${ }^{9}$ Ahmad Wardi Muslich, Hukum Pidana Islam (Jakarta: Sinar Grafika, 2005), 249.
} 
merugikan kepentingan umum, maka perbuatan tersebut dianggap jarîmah dan pelaku dikenakan hukuman. Jenis, kadar dan bentuk hukuman ta'zîr itu terserah kepada kearifan hakim untuk menentukan dan memilih hukuman yang patut dikenakan ke atas pelaku jarîmah tersebut. Apakah hukuman tersebut telah mencapai kata layak sesuai perbuatan yang telah dilakukan pelaku.

Secara garis besar artikel ini membahas tentang sanksi hukum terhadap pelaku penodaan agama menurut menurut Undang-Undang No. 1 Tahun 1965 tentang Pencegahan Penyalahgunaan dan atau Penodaan Agama dan untuk mengetahui perspektif baru mengenai pandangan fiqh jinâyah mengenai sanksi hukum terhadap pelaku penodaan agama dalam Undang-Undang No. 1 Tahun 1965 tentang Pencegahan Penyalahgunaan dan Atau Penodaan Agama.

\section{Sanksi Hukum Pelaku Kejahatan dalam Hukum Islam}

Maksud pokok sanksi hukum adalah untuk memelihara dan menciptakan kemaslahatan manusia dan menjaga mereka dari hal-hal mafsadah, karena Islam itu sebagai rahmah li al-âlamîn untuk memberi petunjuk dan pelajaran kepada umat manusia.

Sanksi hukum harus mempunyai dasar dari al-Qur'an, hadis, maupun lembaga legislatif yang mempunyai kewenangan untuk menetapkan sanksi hukum apabila tidak ditemukan dalam al-Qur'an, hadis, maka dapat dijerat dengan hukuman ta'zîr. ${ }^{10}$ Selain itu sanksi hukum harus bersifat pribadi, artinya hanya dijatuhkan pada pelaku kejahatan itu saja. Hal ini sesuai dengan prinsip bahwa, "seseorang tidak menanggung dosa orang lain". Selain itu, sanksi hukum itu harus bersifat umum, maksudnya adalah sanksi hukum itu berlaku bagi semua individu, karena semua individu itu sama di hadapan hukum. ${ }^{11}$

Mengenai sanksi hukum ini, bahwasanya hukum itu seandainya disyariatkan demi kemaslahatan umum, maka sesungguhnya sanksi hukum itu bukan karena hukumnya merupakan maslahat an sich melainkan karena sanksi hukum tersebut adalah mafâsid atau kerusakan bagi yang dikenai sanksi hukum. Namun kemudian Islam mewajibkan adanya sanksi hukum karena hal ini menuju terpeliharanya kemaslahatan itu. Mungkin saja tindakan-tindakan kejahatan atau pidana itu suatu

\footnotetext{
${ }^{10}$ Ahmad Wardi Muslich, Hukum Pidana Islam (Jakarta: Sinar Grafika, 2005), 249.

${ }^{11}$ Djazuli, Fiqh Jinayah Upaya Menanggulangi Kejahatan dalam Islam, 25-26.
} 
maslahat, namun syariat Islam melarang hal itu bukan karena keadaan delik atau jarîmah tersebut maslahat namun karena jarîmah-jarîmah tersebut menuju atau mengantarkan pada mafâsid, kerusakan.

Sebagai contoh penodaan agama dalam bentuk maraknya aliranaliran baru (sesat) yang mengatas namakan suatu agama, terkadang merupakan suatu yang maslahat bagi pemimpin serta pengikutnya berupa kenikmatan spiritual. Namun maslahat seperti ini tidaklah berarti dalam pandangan Islam.

Lebih jauh, Allah melalui Nabi-Nya melarang untuk berbuat sedemikian itu, bukan karena perbuatannya bermanfaat serta memiliki nilai maslahat, tetapi karena perbuatan itu akan menuju pada kerusakan berupa pembodohan terhadap masyarakat. ${ }^{12}$ Sehingga bisa disimpulkan disini, bahwa sanksi hukum itu mutlak ada karena membuka jalan untuk suatu kemaslahatan. ${ }^{13}$

Kajian terhadap sanksi hukum tidak terlepas dari aspek pidana yang dalam istilah hukum Islam disebut dengan jarîmah.

Definisi jarîmah adalah sebagai berikut:

$$
\text { محظورة شرعية زجر الله عنهما أو تعزير }
$$

"Segala larangan shara" yang diancam dengan hukum had atau ta'zîr. $^{14}$

Had atau h\}udûd ialah sanksi hukum yang kadarnya telah ditetapkan secara s\}arîh berdasarkan nas al-Qur'an maupun hadis, had ini berkaitan erat dengan hak Allah. Hak Allah ialah sanksi hukum dan hak-hak yang terkait pada individu-individu tertentu tetapi manfaat dan tujuan penegakannya bagiseluruh umat Islam atau dengan kata lain semua berkepentingan agar sanksi hukum dan hak-hak ditegakkan. ${ }^{15}$

Ta'zîr merupakan sanksi hukum yang ketetapannya tidak ditentukan secara jelas baik dalam nash al-Qur'an maupun hadis. ${ }^{16}$ Dari definisi tersebut dapat dipahami bahwa jarîmah ta'zîr terdiri atas perbuatan-perbuatan maksiat yang tidak dikenai had ataupun kafârat. Dengan demikian yang menjadi inti jarîmah ta'zîr ialah perbuatan maksiat. Maksiat adalah meninggalkan perbuatan yang diwajibkan dan

\footnotetext{
${ }^{12}$ Juhaya S Praja, Delik Agama, 76-77.

${ }^{13}$ Rahmat Syafei, Ilmu Ushul Fiqh, 139.

${ }^{14}$ Ibid., 11.

${ }^{15}$ Ibn. Taimiyah, Siyasah Syar'iyah Etika Politik Islam, 63.

${ }^{16}$ Ahmad Wardi Muslih, Hukum Pidana Islam, 245.
} 
melakukan perbuatan yang dilarang atau dalam pidana modern diistilahkan dengan delik omisi dan delik komisi. ${ }^{17}$

\section{Penodaan Agama dalam Ketentuan Hukum di Indonesia}

Pada mulanya tidak ada pengaturan khusus mengenai tindak pidana penodaan agama dalam KUHP Indonesia, yang ada adalah berbagai rumusan tindak pidana yang berkaitan dengan kehidupan beragama, atau yang dapat diklasifikasikan menjadi tindak pidana terhadap kehidupan beragama, yaitu dalam pasal 175, 176, dan 177 KUHP. Sedangkan dalam pasal 156a KUHP yang di dalamnya memuat rumusan tindak pidana terhadap agama, yang merupakan pasal amandemen yang disisipkan berdasarkan Penetapan Presiden Republik Indonesia No. 1 Tahun 1965 tentang Pencegahan Penyalahgunaan dan atau Penodaan Agama.

Pada masa itu Penetapan Presiden (Penpres) merupakan produk hukum yang setara dengan undang-undang, yang kemudian dikenal dengan Peraturan Pemerintah Pengganti Undang-undang (Perpu). Selanjutnya, berdasarkan Undang-undang Nomor 5 Tahun 1969 tentang Pernyataan Berbagai Penetapan Presiden dan Peraturan Presiden sebagai Undang-undang, maka kedudukan Penpres tersebut ditingkatkan menjadi Undang-undang, yang kini dikenal sebagai UUPNPS. ${ }^{18}$

Ditinjau dari sejarah pembentukannya, maka penyisipan pasal 156a KUHP tersebut mencerminkan kebutuhan aktual masyarakat Indonesia. Baik pasal 156a KUHP maupun pasal 175-177 KUHP merupakan tindak pidana yang berada dalam Bab V tentang "Kejahatan terhadap Ketertiban Umum”.

Penempatan tindak pidana terhadap agama dan kehidupan beragama dalam Bab tentang "Kejahatan terhadap Ketertiban Umum" dapat diartikan bahwa pada dasarnya "agama" atau "kehidupan beragama" bukan kepentingan yang hendak dilindungi oleh hukum pidana, melainkan kriminalisasi atas perbuatannya itu, karena dianggap berpotensi menggangu ketertiban umum.

Dalam perspektif negara hukum yang menjunjung tinggi HAM, campur tangan negara dalam batas-batas tertentu dapat dibenarkan

\footnotetext{
${ }^{17}$ Ledeng Marpaung, Azas Teori Praktek Hukum Pidana (Jakarta: Ghalia Indonesia, 2003), 21.

${ }^{18}$ Lihat pasal 1 Undang-undang Nomor 5 Tahun 1969 tentang Pernyataan Berbagai Penetapan Presiden dan Peraturan Presiden sebagai Undang-undang.
} 
berdasarkan pasal 28-J ayat (1) dan (2) UUD 1945. Dalam hal ini, pembatasan dalam mengekspresikan kebebasan beragama dimaksudkan demi melindungi kebebasan mendasar dan kebebasan orang lain. Selanjutnya, ketentuan mengenai tindak pidana terhadap agama dan kehidupan di Indonesia masih memerlukan penyempurnaan dan perbaikan, baik dalam lingkup formil dan substansi agar memiliki unsurunsur materiil yang lebih jelas sehingga tidak menimbulkan kesalahan dalam penafsiran dan tentunya dibarengi dengan rincian sanksi hukumnya.

Sebagaimana yang telah disebutkan sebelumnya, tindak pidana terhadap agama seperti yang telah diatur dalam pasal 156a KUHP adalah "pasal amandemen" yang disisipkan berdasarkan pasal 4 UUPNPS, yang berbunyi sebagai berikut:

Pada kitab Undang-undang Hukum Pidana diadakan pasal baru yang berbunyi sebagai berikut:

$$
\text { "Pasal 156a" }
$$

Dipidana dengan pidana penjara selama-lamanya lima tahun barangsiapa dengan sengaja di muka umum mengeluarkan perasaan atau melakukan perbuatan:

a.Yang pada pokoknya bersifat permusuhan, penyalahgunaan atau penodaan terhadap suatu agama yang dianut di Indonesia;

b. Dengan maksud supaya orang tidak menganut agama apapun juga, yang bersendikan ke-Tuhanan Yang Maha Esa.

Sebelum penambahan pasal baru tersebut, tidak dikenal delik agama, meskipun ada beberapa pasal dalam KUHP yang termasuk dalam kategori delik yang berkaitan dengan agama. Sejak konsep RUU KUHP 1993 hingga yang terbaru RUU KUHP 2010, kedua jenis tindak pidana itu dikenal sebagai Tindak Pidana terhadap Agama dan Kehidupan Beragama. ${ }^{19}$ Berdasarkan klasifikasi tersebut, dalam KUHP yang sekarang berlaku, tindak pidana terhadap agama diatur dalam pasal 156a dan tindak pidana yang berkaitan dengan kehidupan beragama tersebar dalam pasal 175-177 KUHP dan psal 503 ke-2 KUHP.

\footnotetext{
${ }^{19}$ Barda Nawawi Arief, Kebijakan Hukum Pidana: Perkembangan Penyusuna Konsep KUHP Baru (Jakarta: Prenada Media Group,2008), 323 (selanjutnya disebut Barda Nawawi Arief I).
} 
Sebelumnya, UUPNPS ini telah diajukan uji materi (judicial review) yang menganggap bertentangan dengan pasal $28 \mathrm{E}$ ayat (1) dan (2); pasal 28 I ayat (1); dan pasal 29 ayat (2) UUD 1945. Meskipun permohonan uji materi yang dituangkan dalam perkara Nomor 140/PUU-VII/2009 tersebut akhirnya ditolak oleh Mahkamah Konstitusi, karena tidak semu dalil yang diajukan permohonan terbukti bertentangan dengan UUD 1945. Namun dalam putusannya MK mengakui bahwa UUPNPS ini memang perlu di revisi. ${ }^{20}$

Dengan demikian, kriteria aliran sesat dalam hal ini merujuk akan penjelasan UUPNS, bahwa aliran atau penganutnya yang dengan sengaja di muka umum menceritakan, menganjurkan atau mengusahakan dukungan umum, untuk melakukan penafsiran tentang sesuatu agama yang dianut di Indonesia atau melakukan kegiatan-kegiatan keagamaan yang menyerupai kegiatan-kegiatan keagamaan dari agama itu, penafsiran dan kegiatan mana menyimpang dari pokok-pokok ajaran agama itu disebut dengan aliran sesat.

Dalam rangka upaya menangkal dan menghentikan aliran sesat serta menyadarkan para pengikutnya agar kembali ke jalan yang benar, MUI Pusat mengeluarkan Pedoman Identifikasi Aliran Sesat pada tanggal 6 Nopember 2007. Dalam pedoman ini ditetapkan sepuluh kriteria sesat, yaitu sebagai berikut: Mengingkari salah satu dari rukun iman dan rukun Islam, meyakini dan atau mengikuti aqidah yang tidak sesuai dengan al-Qur'an dan sunnah, meyakini turunnya wahyu setelah al-Qur'an, mengingkari otentisitas dan atau kebenaran isi al-Qur'an, melakukan penafsiran al-Qur'an yang tidak berdasarkan kaidah-kaidah tafsir, mengingkari kedudukan hadis Nabi sebagai sumber ajaran Islam, menghina, melecehkan dan atau merendahkan para Nabi dan Rasul, mengingkari Nabi Muhammad sebagai Nabi dan Rasul terakhir, mengubah, menambah dan atau mengurangi pokok-pokok ibadah yang telah ditetapkan oleh syariah, seperti haji tidak ke baitullah, salat wajib tidak lima waktu, dan mengkafirkan sesama muslim tanpa dalil syar'i seperti mengkafirkan muslim hanya karena bukan kelompoknya.

Pada umumya, perumusan norma dan saksi tindak pidana terhadap agama dan kehidupan beragama serta pelaku aliran sesat dalam

${ }^{20}$ Putusan Mahkamah konstitusi Nomor 140/PUU-VII/2009 Perihal Pengujian Undang-undang Nomor 1/PNPS/1965 Tentang Pencegahan, Penyalahgunaan dan/atau Penodaan Agama terhadap UUD 1945, (19 April 2010), 298. 
UUPNPS dan KUHP di Indonesia, menjadi satu kesatuan. Sebagaimana telah diketahui, bahwa norma hukum tidak akan ada artinya apabila tidak ada sanksi yang mengaturnya. Ditinjau dari perumusan sanksi, baik KUHP Indonesia maupun dalam UUPNS, mencantumkan dalam pasal yang ayat yang bersangkutan.

Pengaturan sanksi tindak pidana tersebut, sebagian dirumuskan pada awal rumusan pasal, dan sebagian dicantumkan di akhir rumusan tindak pidana. Sanksi yang diterapkan dalam tindak pidana terhadap agama dan kehidupan beragama serta pelaku aliran sesat adalah pidana penjara.

Pasal 156a berasal dari UUPNPS tentang Pencegahan Penyalahgunaan dan atau Penodaan Agama yang dalam Pasal 4 undangundang tersebut langsung memerintahkan agar ketentuan di atas dimasukkan ke dalam KUHP. UUPNPS dengan tegas menyebutkan larangan mengusahakan dukungan umum dan untuk melakukan penafsiran tentang sesuatu agama. Larangan tersebut dimuat dalam Pasal 1, selengkapnya diikuti:

"Setiap orang dilarang dengan sengaja di muka umum menceritakan, menganjurkan atau mengusahakan dukungan umum untuk melakukan penafsiran tentang sesuatu agama yang utama di Indonesia atau melakukan kegiatan-kegiatan keagamaan yang menyerupai kegiatan-kegiatan agama itu, penafsiran dan kegiatan mana menyimpang dari pokok-pokok ajaran dari agama itu."

Sedangkan ketentuan Pasal 156a ini dimasukkan ke dalam KUHP Bab V tentang "Kejahatan terhadap Ketertiban Umum" yang mengatur perbuatan menyatakan perasaan permusuhan, kebencian atau penghinaan terhadap orang atau golongan lain di depan umum. Juga terhadap orang atau golongan yang berlainan suku, agama, keturunan dan sebagainya. Pasal-pasal tersebut dapat dimaknai sebagai penjabaran dari prinsip anti-diskriminasi dan untuk melindungi minoritas dari kewenang-wenangan kelompok mayoritas.

\section{Tinjauan Fiqh Jinâyah terhadap Sanksi Hukum Pelaku Penodaan Agama dalam Ketentuan Hukum di Indonesia}

Dalam fiqh jinâyah, al-Qur'an merupakan sumber hukum Islam yang pertama yang dijadikan dasar pijakan terhadap segala hal yang dihadapi oleh umat Islam. Sedangkan hadis merupakan sumber hukum 
yang kedua setelah al-Qur'an, hadis berfungsi sebagai penjelas, mengurai pandangan atau konsep al-Qur'an dan sebagai praktek amaliah dari alQur'an. Di samping al-Qur'an dan hadis, ada juga sumber lain yaitu ijma' dan qiyas, kedua sumber hukum ini merupakan sumber hukum yang menjadi pegangan mayoritas umat Islam. ${ }^{21}$

Pelanggaran pidana dalam hukum Islam sering disebut dengan jarîmah, yaitu larangan shara' yang diancam dengan hukuman had maupun ta'zîr. Had sendiri merupakan sanksi hukum yang sudah jelas tertera dalam nas al-Qur'an maupun hadis. Sedangkan ta'zîr ialah sanksi hukum yang tidak dijelaskan dalam nas al-Qur'an maupun hadis, hanya dibebankan pada kearifan seorang hakim.

Dalam lanjutannya mengenai sanksi hukum terhadap pelaku aliran sesat yang tidak ditemukan kriterianya dalam al-Qur'an maupun hadis, pelaku aliran sesat dapat dijerat dengan hukuman ta'zîr. Sanksi hukum ini dirasa pantas dan wajar diganjarkan terhadap pelaku aliran sesat. Karena hakim akan menimbang segala perbuatan dan akibat yang telah ditimbulkan oleh pelaku aliran sesat, untuk memutuskan sanksi hukum apa yang akan dijeratkan pada mereka, yang tentunya sesuai dengan tujuan adanya sanksi hukum.

Sanksi hukum ta'zîr merupakan sanksi hukuman yang bersifat mendidik. Ta'zîr memiliki beberapa bentuk hukuman, seperti memenjara, memukul yang tidak sampai melukai. Tidak boleh melaksanakan hukuman ta'zîr berupa memunggut uang (denda) atau mencukur jenggot. Karena hal ini (denda) dinilai sama dengan memunggut harta orang dengan bathil. Meskipun Imam Malik mengatakan kebolehannya menerapakan hukuman ta'zîr berupa denda.

Sanksi pidana lima tahun penjara yang tertera pada UUPNPS, dalam satu sisi dinilai sejalan dengan dengan hukuman ta'zîr yang adalah dalam fiqh jinâyah. Hal ini apabila delik penodaan agama yang dilakukan dinilai ringan. Di sisi lain, sanksi hukum pelaku aliran sesat dalam UUPNS akan sangat bertolak belakang dengan fiqh jinâyah, apabila delik penodaan agamanya dinilai berat. Meruntut sejarah yang ada, ta'zîr yang dikenakan bagi pelaku aliran sesat terberat adalah hukuman dibunuh. Sedangkan dalam UUPNPS, entah besar maupun kecil delik penodaan agamanya, sanksi hukumnya hanya selama-lamanya pidana pejara lima tahun.

${ }^{21}$ Yusuf al-Qardowi, Membumikan Syariat Islam (terj, Muhammad Zaki, dkk), 53. 
Sanksi pidana lima tahun penjara, di satu sisi akan terasa ringan bagi pelaku aliran sesat yang melanggar ketentuan hukum disertai delik pidana lainnya. Sebaliknya akan terasa berat dirasa bagi pelaku aliran sesat yang hanya melanggar secuil ketentuan hukum yang berlaku. Karena itu, sanksi pidana terhadap pelaku aliran sesat harus dijelaskan secara rinci berdasarkan atas delik pidana yang mereka langgar. Tidak bisa dipungkiri, para penegak hukum pun terkadang dihadapkan akan kebingungan dalam penggunaan ketentuan hukum yang mana yang akan dipakai untuk menjerat pelaku aliran sesat.

\section{Simpulan}

Dalam tataran ketentuan hukum di Indonesia, khususnya dalam Undang-Undang Nomor 1 Tahun 1965 tentang Pencegahan Penyalahgunaan dan atau Penodaan Agama maupun KUHP, melihat kriteria mengenai aliran/organisasi yang terlarang atau sesat yang tertuang dalam ketentuan hukum tersebut yang dikuatkan pula oleh fatwa MUI pada tahun 2007, dinyatakan bahwa sanksi hukum terhadap pelaku penodaan agama adalah dengan pidana penjara selama-lamanya lima tahun.

Pandangan Fiqh Jinâyah mengenai penodaan agama dapat ditemui, meskipun sedikit ditemukan dalam nas al-Qur'an maupun hadis yang menjelaskan secara detail mengenai penodaan agama beserta sanksi hukumnya. Penerapan hukuman ta'zîr yang berdasarkan kearifan hakim, digunakan untuk menjerat pelaku penodaan agama. Hukuman ta'zîr disisi lain sejalan dengan sanksi hukum yang ada dalam UUPNPS, hal ini bila delik penodaan agama yang dilakukan dinilai ringan. Tetapi di sisi lain akan sangat bertolak belakang, apabila delik penodaan agama dinilai sangat berat dan besar pengaruh yang ditimbulkan.

\section{Daftar Rujukan}

Adji, Oemar Seno. Hukum (Acara) dalam Prospeksi. Jakarta: Erlangga 1981.

Ali, As'ad Said. Negara Pancasila Jalan Kemashlahatan Berbangsa. Jakarta: LP3ES, 2009.

Arief, Barda Nawawi. Kebijakan Hukum Pidana: Perkembangan Penyusunan Konsep KUHP Baru. Jakarta: Prenada Media Grup, 2008. 
Bajuri (al-), As-Syaikh Ibrahim. Hashiyah 'ala sharh al-alâmah Ibn Qasim al-Gazi 'alâ Matn as-Shaikh Abi Shuja' fi Madhhab asShafi'i. Darul Kitab al-Islamiyyah

Chazawi, Adami H. Hukum Pidana Positif Penghinaan. Surabaya: Penerbit PMN, 2009.

Departemen Agama RI. Al-Qur'an dan Terjemahan dengan Transliterasi. Semarang: Asy-Syifa', 2000.

Doi, Abdur Rahman I. Tindak Pidana dalam Syariat Islam. Jakarta: Rineka Cipta, 1992.

Hakim, Rahmat. Hukum Pidana Islam (Fiqh jinâyah). Bandung: Pustaka Setia, 2000.

Jazuli, A. Fiqh jinâyah, Upaya Menanggulangi Kejahatan dalam Islam. Jakarta: PT. Raja Grafindo Persada, 1997.

Jonkers, JE. Hukum Pidana Hindia Belanda. Jakarta: PT. Bina Aksara, 1987.

Khallaf, Abdul Wahab. Ilmu Ushul al-Fiqh. Kairo: Da'wah Islamiyah alAzhar, tt.

Lamintang. Dasar-Dasar Hukum Pidana Indonesia. Bandung: Penerbit PT Citra Aditya Bakti, 1997.

Mahfudh, MA. Sahal. Ahkamul Fuqaha Solusi Problematika Aktual Hukum Islam, Keputusan Muktamar, Munas, dan Konbes Nahdalatul Ulama' (1926-1999 M.). Surabaya: Penerbit Diantama, 2004.

Majalah Hidayatullah. Sekte Penyembah Kucing. Edisi November, 2008

Marpaung, Ledeng. Azas Teori Praktek Hukum Pidana. Jakarta: Ghalia Indonesia, 2003.

Moeljatno. Kitab Undang-undang Hukum Pidana. Jakarta: Bumi Aksara, 2007.

Muhammad, Rusli. Sistem Peradilan Pidana Indonesia. Yogyakarta: UII Press, 2011.

Munawar (al-), Said Agil. Hukum Islam dan Pluralitas Sosial. Jakarta: Penamadani, 2004.

Muslich, Ahmad Wardi. Hukum Pidana Islam. Jakarta: Sinar Grafika, 2005.

Nasution, Harun. Teologi Islam. Jakarta: UI-Press, 2010. 
Peraturan Pemerintah Nomor 28 Tahun 1969 Tentang Penerapan Undang-undang Nomor 5 Tahun 1969 Tentang Pernyataan Berbagai Penetapan Presiden dan Peraturan Presiden Sebagai Undang-undang

Praja, Juhaya S. dan Ahmad Syihabuddin. Delik Agama dalam Hukum Pidana di Indonesia. Bandung: Penerbit Angkasa, 1982.

Prodjodikoro, Wirjono. Asas-asas Hukum Pidana di Indonesia. Bandung: Pt. Eresco, 1989.

--------. Tindak-Tindak Pidana Tertentu di Indonesia. Bandung: Refika Aditama, 2008.

Putusan Mahkamah konstitusi Nomor 140/PUU-VII/2009 Perihal Pengujian Undang-undang Nomor 1/PNPS/1965 Tentang Pencegahan, Penyalahgunaan dan/atau Penodaan Agama terhadap UUD 1945

Rasjid, Sulaiman. Fiqh Islam. Bandung: Sinar Baru Algensindo, 1994.

Sevilla, Consuelo G. Pengantar Metode Penelitian. Jakarta: UI-Press, 1993.

Sianturi, S.R. Asas-asas Hukum Pidana di Indonesia dan Penerapannya. Jakarta: Alumni AHM-PTHM, 1986.

Sihombing, Uli Parulian. Ketidakadilan dalam Beriman. Jakarta: The Indonesia Legal Resources Center (ILRC), 2012.

Sjadzali, Munawir. Islam dan Tata Negara. Jakarta: UI Press, 1990.

Soejono dan Sri Mamudji. Penelitian Hukum Normatif (Suatu Tinjauan Singkat). Jakarta: Rajawali Pers, 2001.

Sudarto. Hukum Pidana. Bandung: Alumni, 1986.

Syuja', Ahmad ibn Husain asy-Syahir bin Abi. Sharh al-'Alâmah alShaikh Muhammad bin Qasim al-Gazi, al-Musamma Fath alQarîb al-Mujî̀b, (al-Kitab Taqrîb). Nurul Huda, Surabaya.

Undang-undang Dasar Tahun 1945

Undang-undang Nomor 1 Tahun 1965 tentang Pencegahan Penyalahgunaan dan atau Penodaaan Agama

Undang-undang Nomor 5 Tahun 1969 tentang Pernyataan Berbagai Penetapan Presiden dan Peraturan Presiden sebagai Undangundang

Zahra, Abu. al-Jarîmah. Beirut: Dar al-Fikr al- Arabi, tt. 
http://arhamulwildan.blogspot.com diakses pada tanggal 13 April 2003 http://masdarsono.blogspot.com/Negara-dan-diskriminasi-Agama.html diakses pada 21 Mei 2013 